\title{
A Shattered Ulna
}

\section{Uma Ulna Estilhaçada}

Filipa VILABRIL $\triangle^{1}$, Fernando MATOS ${ }^{2}$, Elza PIRES ${ }^{1}$

Acta Med Port 2021 Sep;34(9):624-624 - https://doi.org/10.20344/amp.13444

Keywords: Forearm Injuries; Fractures, Comminuted; Ulna/injuries; Ulna Fractures; Wounds, Gunshot

Palavras-chave: Lesões do Antebraço; Lesão por Arma de Fogo; Fraturas Cominutivas; Fraturas da Ulna; Ulna/lesões

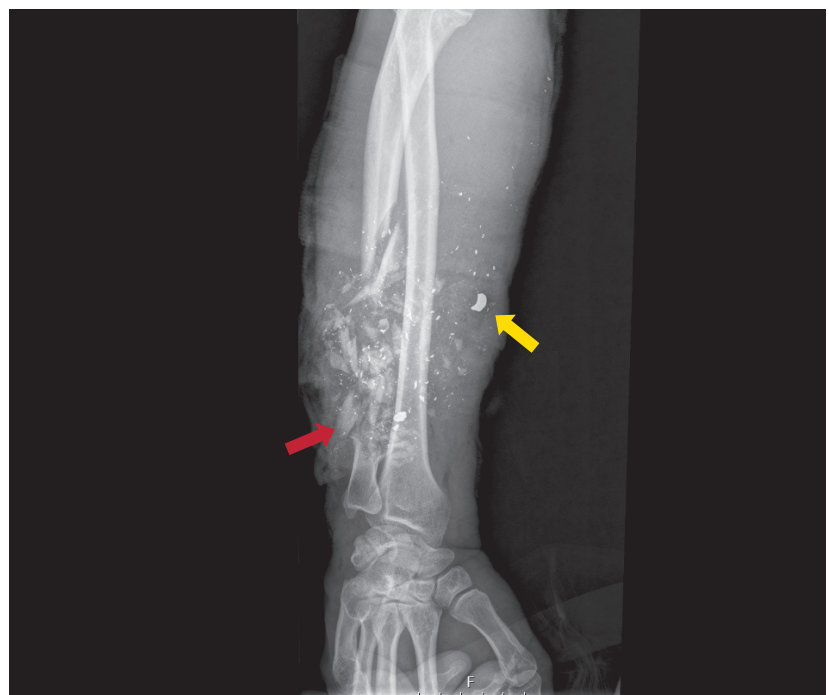

Figure 1 - Radiograph of the right forearm, at admission. Yellow arrow: metallic fragment; red arrow: bone fragment.

A 41-year-old man was admitted to the emergency department with severe gunshot injuries: three penetrating wounds at the volar side and ulnar border of the right forearm, with bone exposure. The radiograph showed an irregular multi-fragmented meta-diaphyseal fracture of the ulna with multiple small metal fragments spread across the forearm (Fig. 1). External fixation was used for stabilization during five months. Two years later, the radiograph showed nonunion of the remaining fragments, that were insufficiently bridged by mature bone (Fig. 2).

Gunshot fractures of the ulna are infrequent and there is scarce literature about their management. ${ }^{1}$ Severe comminution may arise without high local energy transfer, due

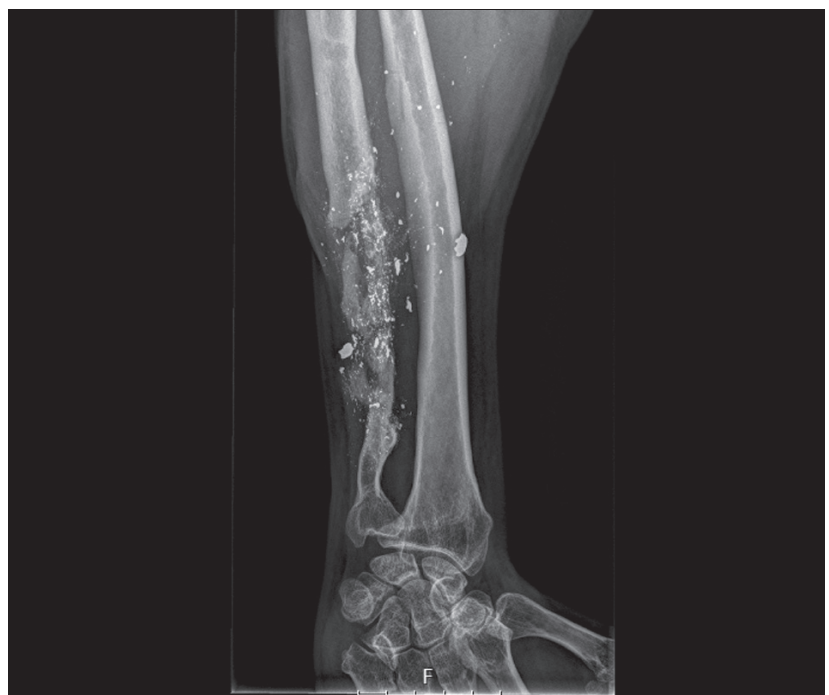

Figure 2 - Radiograph of the right forearm, two years after the injury

either to very fast transfer or to concentration in a small area. ${ }^{2-4}$ Although gunshot injuries often result in neurovascular lesion or infection, ${ }^{1}$ a highly-comminuted gunshot fracture might have a relatively maintained soft-tissue envelope, which must be preserved with an appropriate stabilization method to allow for consolidation. ${ }^{2}$

\section{AUTHORS CONTRIBUTION}

FV: Conception and coordination of the work; draft of the manuscript.

FM: Analysis and description of the images; draft of the manuscript.

EP: Draft of the manuscript; critical review.

PROTECTION OF HUMANS AND ANIMALS: The authors declare that the procedures were followed according to the regulations established by the Clinical Research and Ethics Committee and to the Helsinki Declaration of the World Medical Association. DATA CONFIDENTIALITY: The authors declare having followed the protocols in use at their working center regarding patients' data publication. INFORMED CONSENT: Obtained. CONFLICTS OF INTEREST: All authors report no conflict of interest. FUNDING SOURCES: The authors declare that there were no external sources of study for the performance of this article.

\section{REFERENCES}

1. Mehta SK, Dale WW, Dedwylder MD, Bergin PF, Spitler CA. Rates of neurovascular injury, compartment syndrome, and early infection in operatively treated civilian ballistic forearm fractures. Injury. 2018;49:2244-7.

2. Bowyer GW, Rossiter ND. Management of gunshot wounds of the limbs. J Bone Joint Surg Br. 1997;79:1031-6.

3. Wilson AJ. Gunshot injuries: what does a radiologist need to know? Radiographics. 1999;19:1358-68.

4. Hinsley DE, Phillips SL, Clasper JS. Ballistic fractures during the 2003 Gulf conflict--early prognosis and high complication rate. J R Army Med Corps. 2006;152:96-101.

1. Physical and Rehabilitation Medicine Department. Centro Hospitalar de Trás-os-Montes e Alto Douro. Vila Real. Portugal.

2. Radiology Department. Centro Hospitalar de Tondela-Viseu. Viseu. Portugal.

$\triangle$ Autor correspondente: Filipa Vilabril. filipavilabril@gmail.com

Recebido: 15 de janeiro de 2020 - Aceite: 12 de fevereiro de 2020 - Online issue published: 01 de setembro de 2021

Copyright (C) Ordem dos Médicos 2021 